\section{Filosofi og medisin}

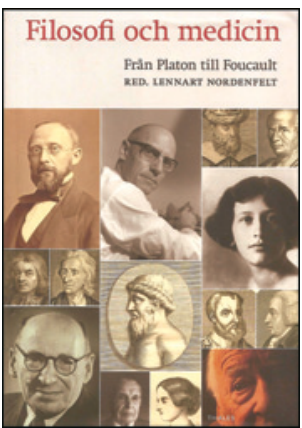

Lennart Nordenfelt, red

Filosofi och medicin

263 s. Stockholm: Thales, 2012. Pris SEK 160

ISBN-978-91-7235-091-5
«En virkelig lege må også være filosof», skrev Galenos. Det gjelder nok mindre i dag enn på Galenos' tid. Men kan man være en god lege uten også å reflektere over sitt virke?

Hva er helse? Hva er sykdom? Hvordan skal sykdommer klassifiseres? Hvordan skal vi forstå smerte og lidelse, og hvilken betydning har de for forståelsen av sykdom? Hva er livskvalitet? Hvordan etableres og utvikles medisinsk kunnskap, hvordan institusjonaliseres den, og hvordan gir den makt? Hva er sammenhengen mellom natur og kultur? Dette er sentrale spørsmål for medisinen og for filosofien.

Filosofen Lennart Nordenfelt har samlet en rekke dyktige svenske kolleger til å presentere sentrale tenkere og deres bidrag for å forstå og drøfte slike spørsmål. Her finner vi Platon, Cicero, Galenos, Avicenna, Sydenham, Locke, Cullen, Virchow og Fleck, men også Nightingale, Gadamer, Canguilhem, Weil og Foucault. Hver tenker presenteres med liv og levned, tanker og virkningshistorie, der linjene trekkes frem til dagens debatter. Flere av de omtalte personene er både leger og filosofer.

Målgruppen er reflekterte leger, helseinteresserte filosofer og andre interesserte. Boken er velskrevet og godt redigert, med tydelige krysshenvisninger og kort noteverk. Hvert kapittel kan leses separat, men sammenhengen gir ekstra innsikt.

Mange store tenkere er ikke med, og flere viktige spørsmål og perspektiver blir ikke behandlet. Slik må det være i en antologi som denne. I mange av kapitlene ville jeg også gjerne hørt tenkernes egne stemmer tydeligere, men det er utfordrende med så begrenset plass. På tross av dette får vi en god oversikt over de ulike tenkernes bidrag, som pirrer til videre lesning og fordypning.

Flere moderne filosofer har skrevet om filosofi som terapi. Den terapeutiske virkningen av å lese Filosofi och medicin er enda ikke dokumentert. «Virkningsmekanismene» er dog kjent: refleksjon, perspektivrikdom og dannelse. Min (spekulative) prognose (basert på egen lesing, $\mathrm{n}=1$ ) er at den kan være til glede og berikelse for mange.

\section{Bjørn Hofmann}

Høgskolen i Gjøvik

og

Universitetet i Oslo

\section{Det er størrelsen på frakkelommen det kommer an på}

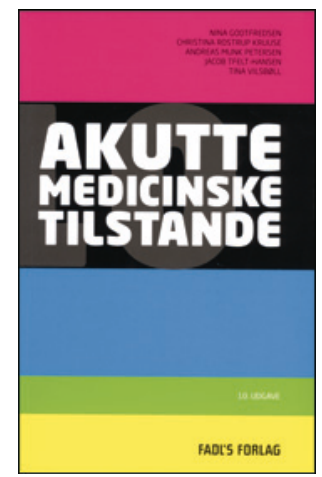

Nina Godtfredsen, Christina Rostrup Kruuse, Andreas Munk Petersen et al.

Akutte medicinske tilstande

10. utg. 349 s, tab, ill. København: FADL's

Forlag, 2013. Pris DKK 300

ISBN 978-87-7749-639-6

Utvalget av bøker som skal komme ferske turnusleger til unnsetning i akuttmottaket, er stort. Man kan velge mellom bøker tilpasset norske forhold eller internasjonale bestselgere. I tillegg kommer lokale metodebøker og elektroniske oppslagsverk. Trenger vi da en ny dansk bok?

Denne frakkelommeboken er skrevet for turnusleger og studenter som arbeider ved danske akuttmottak. Kapittelinndelingen er klassisk etter organsystemer. Det er enkelt å finne frem i stikkordregisteret som dekker både symptombilder og diagnoser. Illustrasjonene og tabellene er gode, men ikke så mange. Bokens avgrensning til kun indremedisinske tilstander gjør at forfatterne kan tillate seg å gå mer i dybden og drøfte årsaker, forløp og komplikasjoner etter akuttfasen enn hva man i tilsvarende bøker gjør. Det går på bekostning av kirurgiske differensialdiagnoser. Kapitlene om elektrolyttforstyrrelser og forgiftninger er svært gode og innholdsrike. De har kommet meg til unnsetning på vakt når det kimer $\mathrm{i}$ callingen fra «intensiven». Eksempler på typiske EKGer og blodgassverdier gjør at læringsutbyttet heves. Boken er velskrevet. Beskrivelsen av hver diagnose følger en standardmal med symptomer, differensialdiagnoser, supplerende undersøkelser og videre behandling.

Beskrivelser av behandling inneholder doseringer og utregningstabeller. Medikamenter beskrives med virkning, f.eks. betaagonist, deretter dansk salgsnavn, men generisk navn utelates ofte. Problemet er at danske og norske salgsnavn kan være ulike. Jeg ser for meg situasjonen der turnuslegen står med sin første eksaserbasjon av kols. Den flittige turnuslegen har lest seg opp mens pasienten er på vei inn, og føler seg nesten forberedt på det han/hun tror venter. Med tilgjort selvsikkerhet ber legen høflig om administrering av Berodual eller Combivent inhalasjon. I ett forsøk på å redde situasjonen spør sykepleieren om det er Atrovent og Ventoline legen mener? Turnuslegen får samme farge som pasienten, misforståelsen er et faktum, og førsteinntrykket $i$ akuttmottaket er levert.

Boken er ypperlig for danske forhold, men små forskjeller mellom det danske og det norske helsevesenet byr på unødvendige utfordringer for turnusleger i Norge. Omslagets lett tilgjengelige HLR-sløyfe er for eksempel ulik den norske. Dette kan føre til misforståelser i akutte situasjoner, der samarbeid i et enhetlig team er essensielt for et godt resultat.

Jeg vil anbefale denne boken for den interesserte turnuslege som ønsker å lese litt mer om indremedisinske tilstander man møter på vakt. Men som regel er det bare plass til én bok i frakkelommen, og en bok tilpasset norske forhold ville heller fătt plassen i min lomme. En annen svakhet ved denne boken er at ja, det er en bok. Med oppdaterte elektroniske løsninger er kanskje frakkelommebokens tid forbi?

Benedikte Ræder

Kristiansund sykehus 